Maya Keliyan ${ }^{1}$

Bulgarian Academy of Sciences, Institute of Philosophy and Sociology

Sofia (Bulgaria)
316.728:[616.98:578.834(497.2)"2020"

379.8:316.023(497.2)"2020"

Review scientific paper

Submitted 26/01/2021

Revised 16/03/2021

Accepted 16/03/2021

doi:10.5937/socpreg55-30552

\title{
LEISURE IN BULGARIA
}

Abstract: The article examines the leisure patterns in Bulgaria in comparison with other EU countries, analyzing data from Eurostat, National Statistical Institute, European Quality of Life Survey, results from the project "Local festivals: A resource of local communities for coping with crises", etc. Bulgarians actively use the internet and social networks, but we have the difficulties to achieve a balance between work, family, and social contacts. Low incomes negatively affect leisure activities by limiting them in order to meet the basic needs of the households. Lockdown, caused by the COVID-19 pandemic, led to an increase in leisure time, but the possibilities for its use have significantly decreased. The extensive use of telework blurs the boundaries between working time and leisure.

Keywords: leisure, Bulgarian leisure patterns, community cultural centres, COVID-19 pandemic

The pandemic of the new coronavirus COVID-19 has a huge impact not only on human health and health systems of societies, it has caused a series of crises: economic, social, mental and others. It has also caused significant changes in the lifestyles of modern societies: on their consumption and leisure. The patterns of mass consumption and leisure are being reconsidered during periods of full or partial lockdown, by the imposed measures of social distance and isolation. In the COVID-19 pandemic many planned leisure activities are postponed for "better times". If we borrow Juliet Schor's expression "cannibalization of leisure" (Schor, 1992), which she uses to explain another social phenomenon related to leisure patterns, in the current pandemic, free time is "cannibalized" for all of us. The boundaries between work and leisure are changing due to the increase in telework. The described changes affect all European societies, but their specific dimensions are manifested depending on the peculiarities of leisure patterns, the balance between work and leisure, which existed before the pandemic in each particular society. Attitudes towards leisure are being reconsidered: they start to be conceived as constituting feelings of a "return" to "the normality" before the crisis and inspire social optimism. In some sense leisure activities are the antipode of fear and social isolation; they represent an instrument for overcoming the effects of social isolation.

1 mayakeliyan@gmail.com 
The goal of the article is to study the leisure patterns in contemporary Bulgaria in comparative perspective with leisure patterns in other EU member states, in order to arrive to the conclusions about similarities and differences between them. Leisure is part of the reward structure of a social system with differential access to resources based largely on socioeconomic position. The resources of time, money, access, and autonomy are evidently unevenly distributed in any society (Kelly, 1972), as well as every modern society has different resources, traditions and leisure culture.

We assume that leisure can be defined as the time and activities outside paid labour; leisure activities are performed by choice, they are other than duties and necessities. Leisure patterns are the characteristic, typical, distinctive activities, fixed by the social-groups in certain social categories, groups, and strata, which the latter choose to perform. The more developed a society is, the greater the freedom of its members (all other things being equal) to form their consumption and leisure patterns. We also consider as relevant to the leisure patterns the specific attitudes, evaluations, expectations, and degree of satisfaction regarding the patterns one is following, as well as the desire eventually to change them (Keliyan, 2012, pp. 37-40) $)^{2}$.

An important role in the cultural life of Bulgaria and the focus of leisure activities of a large part of the population are the community cultural centres, chitalishte - a unique national cultural phenomenon ${ }^{3}$. This important institution arose during the Revival period, and has retained its importance for cultural life in this country down to our times. The name chitalishte in Bulgarian literally means "reading centre". The first of these appeared in 1856 , and by the time of the Liberation of Bulgaria from Ottoman rule in 1878 they numbered as many as 130 . These cultural centres of the local community in the past were and they still are a venue for amateur artistic activities, and they included a library, an amateur theatre, amateur musicians and dance groups, various club activities; performances, lectures, and other events were held there, and over time they became firmly established as a focal point for the life and leisure of various social groups and categories of Bulgarians. Chitalishte was registered in 2017 by $\mathrm{UNESCO}^{4}$ as a "practical experience in safeguarding the vitality of the Intangible Cultural Heritage" (Culture statistics 2019 edition, 2019, p. 29). According to the law that regulates its activities, the chitalishte is a traditional self-governing Bulgarian cultural and educational association in the settlements, which also performs state cultural and educational tasks. All individuals can participate in its activities, regardless of age and gender restrictions, political and religious views and ethnic identity. Community cultural centre is non-profit legal entity - NGO.

As of December 31 $1^{\text {st }}, 2017$, there were 3,321 local community cultural centres functioning in Bulgaria, of which 663 in the cities and 2,658 - in the villages (National Statistical

2 See file:///C:/Users/user/Downloads/Pecob_Volume_Keliyan.pdf

3 The cited data and conclusions are based on results obtained from a study within the project "Local festivals: A resource of local communities for coping with crises", funded by National Science Fund - Ministry of Education and Science (KP-06-H45/5 of 30 ${ }^{\text {th }}$ November 2020).

${ }^{4}$ The UNESCO Register of Good Safeguarding Practices, which was set-up in 2009, collects significant safeguarding experiences and examples of how communities around the world successfully face and solve challenges in the transmission of their living heritage, with a collection of best practices and knowledge that can be adapted to other circumstances for future generations. 
Institute ${ }^{5}$ ). Their activities are expanding and growing more varied; today, in addition to the traditional amateur theatrical, dance, and singing groups, interest groups in the arts, etc., they also provide the very popular, in the last 30 years, courses for foreign languages, computer skills, modern sports and relaxation practices, various forms of social contact, etc.

In 2017, the local community cultural centres organized a total of 21,267 commemorial of notable dates, 7,130 discussions of books, 24334 celebrations and festivals and 3,762 gatherings. There were arranged 1001 museum collections, presented 4,245 cinema and video shows, and they managed 1,253 other cultural activities. Just under half of the chitalishte in Bulgaria (48.7\%) provided computers with internet for users; almost all of them had an operating library $-91.7 \%$, and more than three quarters of them $-76.6 \%$ had an auditorium (National Statistical Institute ${ }^{6}$ ).

Chitalishte are centres of amateur artistic creativity in both towns and villages; they are the cultural institutions that organize and promote it. In 2017, a total of 4,607 groups and formations for music and singing were functioning in them, of which 1,629 were in the cities and 2,978 in the villages. The most numerous among them were the groups for authentic folklore singing $-2,778$, in whose activities 30,816 people participated. Other 56,640 people took part in the functioning 3,178 groups for dance art, among which the most popular were the dance groups for authentic folklore - 2,386, with 44,593 amateur dancers.

In 2017 in the local community cultural centres 3,077 clubs and study circles had been established, of which 1,327 were in the urban areas and 1,750 - in the rural areas, and a total of 39,375 people participated in their activities, of which 20142 were city dwellers and 19,233 -rural areas' inhabitants. These amateur art clubs performed a total of 13,985 performances in 2017, among which the most numerous were theatrical productions, followed by exhibitions in the field of applied arts $-2,197$ and in the field of fine arts $-1,696$, respectively (National Statistical Institute ${ }^{7}$ ).

In many small towns, as well as in the rural regions, the chitalishte are the only cultural institutions; without their activities people living in these parts of the country would be deprived of any opportunity to attend cultural events, as well as to take part in them. It is no coincidence that it is called narodno chitalishte - "people's community centre".

Bulgaria has been a member of the EU for 13 years now and the condition and the development of our society is compared to those in the other member states of the Union in a number of indicators. What are the trends in the leisure patterns in our country, compared to those observed in the EU? What are the similarities and differences between us and to what extent do the leisure activities in our country approach (or move away) from those in developed European societies? The information provided by the statistical office of the European Union - Eurostat, by National Statistical Institute of our country, as well as by the European Quality of Life Survey (EQLS), etc., is a good basis for studying leisure in Bulgaria, as well as for comparing it with that shown in other EU member states.

\footnotetext{
${ }^{5}$ https://www.nsi.bg/en/content/4537/community-clubs, accessed on December $30^{\text {th }} 2020$.

${ }^{6}$ https://www.nsi.bg/en/content/4543/amateur-artistic-creativity-community-cultural-centres, accessed on December $30^{\text {th }} 2020$.

${ }^{7}$ https://www.nsi.bg/en/content/4543/amateur-artistic-creativity-community-cultural-centres, accessed on December $30^{\text {th }} 2020$.
} 
According to Eurostat data, the frequency of contacts of Bulgarians with relatives, friends and neighbours as a leisure activity in 2015 was close to the EU average, although we are not among the countries with the highest relative shares of a similar kind of communication. Bulgaria ranked $13^{\text {th }}$ among other countries, with $23.8 \%$ of women surveyed and $22.8 \%$ of men studied said they met with relatives, friends and neighbours several times per month. The EU average was $23.5 \%$ for women and $22.5 \%$ for men (The lives of women and men in Europe, $2018^{8}$ ).

According to indicators taking into account the participation in a number of leisure activities, Bulgaria is on the penultimate place among the other EU countries, followed by Romania. These activities include practicing some kind of sport, going to the cinemas, attending live performances, visiting cultural sites and attending sporting events. The relative share of Bulgarians who played sports in 2014 was low: men and women who spend 150 or more minutes a week for sports or for non-work-related physical activity in our country was $15.3 \%$ for men and only $5.3 \%$ for women. The relative share of men exercising in their free time averaged $37.5 \%$ for the EU and $26.2 \%$ for women, respectively. The data show that the men in Bulgaria who chose sports as a leisure activity in 2014 were almost two and a half times less than the EU average, and the Bulgarian women performing this activity were almost five times less than the women in the rest member states of the Union. One of the reasons for the insufficient activities of Bulgarians in sports is the poor, unsatisfactory or inaccessible (for a number of reasons - financial, infrastructural and others) material base, where one could play sports in his or her free time. Bulgaria had the lowest level of satisfaction with sports facilities in the capital city in 2014, with Sofia ranking last among other EU capitals: only more than a third (38\%) of its inhabitants found their city's sports facilities as "good enough".

In 2015, some $63.7 \%$ of the EU adult population (aged 16 years or more) reported that they went to the cinema, attended a live performance (theatre, concert, organized cultural event outdoors and so on) or visited a cultural site (museum, historical monument, art gallery or archaeological site) during the previous 12 months. One of the lowest levels of cultural participation was recorded in Bulgaria - 28.6\%. For residents in the rural areas in our country this share was the lowest shown in Europe, below 10\% (Cultural statistics 2019 edition, 2019 , p. 125 , p. 139).

In 2015, the share of the EU adult population (aged 16 years or more) that reported that they pursued at least one artistic activity (during the 12 months prior to the survey) stood at just over one third (35.2\%), while in Bulgaria this share was about $17 \%$, or twice less than EU average. There were about $83 \%$ of Bulgarians that did not practice any cultural activity during the same year (Ibid, p. 143).

Data on going to the cinema up to three times in the last 12 months for the EU averaged $28.6 \%$ for women and $27.4 \%$ for men; only $12,6 \%$ of women (or 2.3 times less than the EU average) and $13.6 \%$ of men (respectively two times less than the average for EU) in our country have stated they went to the movies. It is important to note that $20 \%$ of surveyed Bulgarians have chosen "the lack of interest" as main reason not to go to the cinema and less than a fifth of the respondents $(18 \%)$ pointed to financial reasons as the main motive for not going to the movies.

${ }^{8}$ https://www.nsi.bg/women_and_men_in_Europe_2018/bloc-3b.html?lang=bg, accessed on December $30^{\text {th }} 2020$. 
The trend observed for the "going to the cinema" indicator is repeated for that of „visits to live performances": the average relative share for the EU was 30.3\% for women and $27.7 \%$ for men. The share of Bulgarian women attending live performances was $14 \%$ (2.2 times less than the EU average), and men - 11.3\% (respectively two and a half times less than the EU average). The main reason for not participating in this kind of cultural activity was again "lack of interest", shown by $23 \%$ of respondents, and "financial reasons" - by $18 \%$ of interviewed Bulgarian.

The average relative share for women in EU countries, who had visited cultural sites was $28 \%$, and for men $-27.3 \%$. In Bulgaria, this percentage of women, was two and a half times lower than the EU average, and for men it was even three times lower than the European average. The main reason for not participating in this kind of cultural activity was "lack of interest", shown by $28 \%$ of respondents, and "financial reasons" - by $17 \%$ of interviewed Bulgarian.

A popular leisure activity of Bulgarians is reading books. In 2016, the relative share of women who read at least one book in the last 12 months was $61.2 \%$, and of men $-45.1 \%$, respectively. As can be seen from the cited data, women were more active book readers than men, with a difference of $16 \%$ between both sexes. $48.5 \%$ of Bulgarian men and $42.7 \%$ of women have read newspapers every day or almost every day, with the difference between them being just under 6\% (The lives of women and men in Europe, 2018 ${ }^{9}$ ).

In Bulgaria in 2018 were registered the lowest relative shares of households with access to the internet among EU member states - $72 \%$, while EU average for this indicator for the same year was $89 \%$ (Culture statistics 2019 edition, 2019, pp. 153-154). Despite the lower spread of the internet in comparison with European countries, we were among the EU member states that actively use the network. In 2017, the average relative shares for men and women between the ages of 16 and 74 who used the internet during last three months before the survey, in the EU average level were $63 \%$ for the former and $67 \%$ for the latter. For women in Bulgaria this share was $82 \%$, and for men $-76 \%$, which was respectively $15 \%$ more for the former and $13 \%$ more for the latter, compared to the EU average. According to the cited indicator, Bulgaria was situated in the fourth place after Malta, Hungary and Belgium. The internet and the opportunities it offers are used in Bulgaria mainly in leisure activities, and not, as it was in most EU countries, for work-related purposes. For example, according to the indicator "use of the internet for job search and application", the average values of the relative shares of women and men in the member states was respectively one-fifth for each group, while for Bulgaria these values was half of the average for the Union - respectively $11 \%$ for women and $10 \%$ for men, and we were in the penultimate place before the Czech Republic. The internet for sending and receiving emails in the EU was used by an average of $87 \%$ of men and $86 \%$ of women, and Bulgarians were not among the most active users of the network in this regard: $71 \%$ of women and $70 \%$ of men in Bulgaria used it for such a purpose.

The relative share of Bulgarians reading online news was close to the average in EU countries: the percentage of women in the EU reading news online was on average $70 \%$, while among Bulgarian women it was $74 \%$; men in the EU who used the internet to read news had a relative share of 75\%, and those in Bulgaria -respectively 74\%.In 2018 near a

\footnotetext{
${ }^{9}$ https://www.nsi.bg/women_and_men_in_Europe_2018/bloc-3b.html?lang=bg, accessed on December $30^{\text {th }} 2020$.
} 
half (47\%) of Bulgarians were watching internet streamed TV or videos and were listening to the music; a fifth of respondents from our country were playing or downloading games. For comparison EU average for watching internet streamed TV or videos for the same period was less than three-quarters (72\%), more than a half (56\%) were listening to the music, and a third - were playing or downloading games (Culture statistics 2019 edition, 2019, p.160, p. 155).

The share of people in the EU making online purchases of any goods and services was $69 \%$ in 2018 , and the share of those purchasing tickets for events was $27 \%$. The proportion of internet users purchasing books, magazines and newspapers online was $22 \%$, and the share of those buying online films and music was $17 \%$. By contrast, less than $10 \%$ of internet users in Bulgaria made online purchases of films or music - 1\%, of books, magazines and newspapers $-2 \%$, or of tickets for cultural events $-5 \%$. Less than a third of Bulgarians made online purchases of any goods (Ibid, pp. 168-170).

The involvement of Bulgarians in voluntary activities in their leisure time is an extremely unpopular activity, which determines the low civic activity in the country. The share of the adult population that participated in voluntary activities in Bulgaria in 2015 was less that $10 \%$ (Living conditions in Europe, 2018, p. 119).

There are significant structural differences in the budget expenditures of households for the EU average and those in Bulgaria: the households' expenditures on culture for EU average in 2018 were $3 \%$ of their total expenditures, while for Bulgarian households these expenditures were $1.6 \%$ of their total expenditures. While $42 \%$ of all expenditures of Bulgarian households on culture were for the payment of TV and radio fees, rental of equipment and accessories for these services, the average relative share of expenditures on the same items for the EU were half as low- 20\% (Ibid, p. 183).

The division of labour in the family and the involvement in household maintenance activities, such as cleaning, cooking, shopping, home care, care for household members, etc. has a decisive impact on women's and men's leisure opportunities. The relative share of women in the EU member states, occupied on a daily basis with cooking and housekeeping in 2016 was $79 \%$, while that of men was $34 \%$ respectively. Near three-quarter (73\%) of Bulgarian women are engaged in different activities in the field of domestic work, i.e. it was $6 \%$ lower than the EU average. But the share of Bulgarian men doing the same domestic work was $13 \%$, or 2.6 times lower compared to their European counterparts. According to the indicator „reported the largest difference between the participation of men and women in domestic work", Bulgaria was in third place after Greece and Italy. Bulgarian men, together with their Croatian counterparts, compared to men in other EU countries, participated the least in housekeeping activities, respectively - 13\% involvement of Bulgarians and 12\% of Croats in cooking and housekeeping (The lives of women and men in Europe, $2018^{10}$ ).

In 2019, people in the EU worked on average 37.1 hours a week in their main job. In 2019, employees in Bulgaria had the longest average working week among the EU countries - 40.4 hours per week (The European Union Labour Force Survey ${ }^{11}$ ).

${ }^{10}$ https://www.nsi.bg/women_and_men_in_Europe_2018/bloc-3b.html?lang=bg, accessed on December $30^{\text {th }} 2020$.

${ }^{11} \mathrm{https} / /$ ec.europa.eu/eurostat/databrowser/view/lfsa_ewhuis/default/table?lang=en, accessed on December $30^{\text {th }} 2020$. 
According to Eurostat data for $2019,9 \%$ of respondents in Bulgaria answered they feel always time pressure when work, $31 \%$ - feel often pressure; $51 \%$ - sometimes, and 9\% - never ${ }^{12}$. We can arrive to the conclusion that Bulgarians were working in time pressure working environment.

We also had the biggest problem achieving a balance between work, family, and social contacts. The surveyed Bulgarians indicated the greatest degree of difficulties in finding the time and energy to fulfil domestic and family tasks and in concentrating sufficiently at work. When looking at the breakdowns by gender, women in Bulgaria experienced more work-life balance related problems. They also experienced a faster deterioration in worklife balance than men. For instance, in 2016, 70\% of women reported being "too tired from work to do some of the household jobs which need to be done" at least several times a month, compared with 68\% of men (European Quality of Life Survey 2016: Quality of life, quality of public services, and quality of society, 2017, pp. 41-42).

Low incomes affect negatively leisure activities by limiting them in order to meet the basic needs of households. During the years of its membership in the EU, Bulgaria permanently retains the last place in terms of incomes. According to Eurostat data, while the average hourly wage in the EU in 2019 for men was 16.64 Euros and for women - 13.72 Euros, in Bulgaria it was 2.52 Euros for men and 2.16 Euros for women. Low incomes also determine the corresponding quality of life in Bulgarian society ${ }^{13}$.

Actual individual consumption (AIC) is a measure of material welfare of households. According to Eurostat data for 2019, AIC per capita expressed in Purchasing Power Standards (PPS) in Bulgaria was 58\% of the EU average level. In 2019, GDP per capita expressed in PPS in Bulgaria was $53 \%$ of the EU average (Ibid)

Feeling of happiness in Bulgaria in 2016 was measured 6.4, below the EU averages of 7.4. This phenomenon could be explained by the economic difficulties and deprivations in which a significant part of the Bulgarian population lives. The share of respondents reported difficulties making end meet - in 2016 was 63\%, still higher than the EU average of 39\% (European Quality of Life Survey 2016: Quality of life, quality of public services, and quality of society, 2017, pp. 14-16).

The COVID-19 crisis has caused far-reaching changes over a very short period of time. “The Living, Working and COVID-19” Eurofound 2020 e-survey provides an insight into the impact of the pandemic on people's lives in EU member states. The e-survey with data collected online was conducted in April 2020, at the beginning of COVID-19 pandemic and again three months later, in July 2020.

Public health measures designed to stem the spread of COVID-19 have included the active encouragement of home working for those in a position to do so. With many workplaces in enforced closure from spring 2020, teleworking became the customary mode of working for many employees who had limited or no previous experience of working in this way. Respondents who worked from home more often report working in their free time, especially when there are children in the household. Telework has also proved to be burdensome for many working mothers as they juggle work, home-schooling and care, all in the

12 https://ec.europa.eu/eurostat, accessed on December $30^{\text {th }}, 2020$.

13 https://ec.europa.eu/eurostat/documents/portlet_file_entry/2995521/2-15122020-BP-EN.pdf/ cd3fcb0f-faee-d0ce-0916-9be3ac231210, accessed on December 30 ${ }^{\text {th }}, 2020$. 
same pocket of space. Teleworking is likely to become much more commonplace post-crisis based on the generally positive response of employees and employers to the COVID-19 teleworking experience. However, more extensive telework means increasingly blurred work-life boundaries, and makes large segments of workers being at risk of physical and emotional exhaustion.

The e-survey in April 2020 revealed that respondents - especially women with children under 12 - were struggling to balance their work and personal life. Indeed, although teleworking was a key factor in ensuring business continuity, it has led to a rise in the number of people working from home, resulting in difficulties in managing work-life conflicts and an increase in the incidence of overtime work. The relative share of employed persons in Bulgaria working from home as a percentage of the total employment was very low in $2019-0.6 \%$, followed only by Romania. The average share for the EU member states for the same period on this indicator was $10.8 \%$. The COVID-19 pandemic has changed employment patterns in Europe, with the relative share of teleworking increasing significantly in 2020: the EU average was $34 \%$ or slightly more than a third of those employed, while for Bulgaria this percentage was $22 \%$ or between one fifth and one quarter of employed Bulgarians (Eurofound, 2020) ${ }^{14}$.

Among all EU member states, the highest proportion of surveyed Bulgarians reported the deterioration of their financial situation in July 2020 compared to that in April: $49 \%$ indicated this answer in July against 39\% in April, compared to EU averages of 34\% and $30 \%$ respectively. This undoubtedly affects Bulgarians life satisfaction ${ }^{15}$. For total EU 27 member states mean of life satisfaction in April was 5.5 and in July - 5.2: this mean for Bulgaria was 6,7 in April and 6.3 in July, which indicates lower level of life satisfaction compared to other countries (Ibid).

On the one hand, due to lockdown, free time increases. But, on the other hand, due to the closure of leisure centres, concert halls, the suspension of theatre productions, operas, performances, etc., the possibilities for its use have significantly decreased. But, at the same time, other such opportunities appear - for online activities, communication, concerts, even for some kind of sports (for example, online yoga courses), etc., for activities at home. For some social groups, as a result of the pandemic, free time increases, and for others it significantly decreases - for example, for the parents of children who study online, for those who work online, for teachers and others.

The conclusion we can draw is that the pandemic has changed and even to some extent erased the boundaries between working time and leisure.

${ }^{14}$ http://eurofound.link/covid19data, accessed on December $30^{\text {th }} 2020$.

15 Life satisfaction is measured on a scale of 1 to 10 , where 1 means very dissatisfied and 10 means very satisfied. 
Маја Келијан ${ }^{1}$

Бугарска академија наука,

Институт за филозофију и социологију

Софија (Бугарска)

\title{
ДОКОЛИЦА У БУГАРСКОЈ
}

\author{
(Превоg In Extenso)
}

Сажетак: Овај чланак истражује обрасце доколице у Бугарској у поређењу са осталим државама чланицама ЕУ, анализирајући податке добијене од Eurostat-a, Националног завода за статистику Бугарске, Европске анкете о квалитету живота, као и резултате пројекта „Локални фестивали: начин на који се локалне заједнице боре против криза" итд. У Бугарској активно користе интернет и друштвене мреже, али нам је тешко да постигнемо равнотежу између посла, породице и друштвених контаката. Ниски приходи негативно утичу на активности у слободно време, ограничавајући их захтевом за задовољавањем основних потреба домаћинстава. Затварање проузроковано пандемијом COVID-19 довело је до повећања слободног времена, али су могућности његовог коришћења знатно смањене. Широка примена рада на даљину променила је границе између радног и слободног времена.

Кључне речи: доколица, обрасци доколице у Бугарској, културни центри у оквиру заједнице, пандемија COVID-19

Пандемија новог коронавируса COVID-19 има огроман утицај не само на људско здравље и здравствене системе у друштвима, већ је изазвала и низ криза: економску, друштвену, менталну и друге. Она је такође проузроковала значајне промене у начину живота у модерним друштвима: у потрошњи и доколици. Преиспитују се обрасци масовне потрошње и доколице током периода потпуног и делимичног затварања, а у односу на уведене мере социјалне дистанце и изолације. Током пандемије COVID-19, велики број планираних слободних активности одложен је за „боља времена”. Ако позајмимо термин који је сковала Џулијет Шор - „канибализација доколице” (Schor, 1992) - који она користи да би објаснила још једну друштвену појаву везану за обрасце доколице, у текућој пандемији се слободно време „канибализује” за све нас. Границе између посла и слободног времена се мењају услед повећаног рада на даљину. Описане промене утичу на сва европска друштва, али се њихове посебне димензије испољавају у зависности од специфичних образаца доколице и равнотеже између посла и доколице који су постојали пре пандемије у сваком појединачном друштву. Ставови према доколици се преиспитују: почињу да се сматрају

\footnotetext{
1 mayakeliyan@gmail.com
} 
стварањем осећања о „повратку” у „нормалност” пре кризе и подстичу друштвени оптимизам. У извесном смислу, активности у слободне време представљају потпуну супротност страху и друштвеној изолацији; оне представљају инструмент за превазилажење ефеката друштвене изолације.

Циљ овог чланка јесте проучавање образаца доколице у савременој Бугарској у упоредној перспективи са обрасцима доколице у другим државама чланицама ЕУ, како би се донели закључци о сличностима и разликама између њих. Доколица је саставни део структуре награђивања у друштвеном систему са различитим приступом ресурсима у великој мери заснованим на друштвено-економском положају. Ресурси као што су време, новац, приступ и аутономија очигледно су неравномерно распоређени у сваком друштву (Kelly, 1972), а и свако модерно друштво има различите ресурсе, традиције и културу доколице.

Претпостављамо да се доколица може дефинисати као време и активности ван плаћеног посла; активности у слободно време обављају се на основу избора и представљају нешто другачије од дужности и потреба. Обрасци доколице су карактеристичне, типичне и препознатљиве активности које утврђују и бирају друштвене групе у оквиру одређених друштвених категоријама, групација и слојева. Што је друштво развијеније, већа је слобода коју његови припадници имају (ако су једнаке све остале ствари) у обликовању својих образаца потрошње и доколице. Такође сматрамо да су за обрасце доколице релевантни и посебни ставови, процене, очекивања и степен задовољства када је реч о обрасцима које неко прати, као и потенцијалној жељи да се они промене (Keliyan, 2012, str. 37-40)2.

Важну улогу у културном животу Бугарске и средиште активности доколице великог дела становништва представљају културни центри заједнице, познати као читалиште - реч је о јединственом националном културолошком феномену․․을 значајна институција појавила се током периода обнове и задржала је свој значај у културном животу ове земље све до данас. Назив „читалиште” на бугарском дословно значи „центар за читање”. Прва читалишта појавила су се 1856. и до 1878. године, када се Бугарска ослободила отоманске власти, било их је чак 130. Ови културни центри локалне заједнице су у прошлости били и остали место за аматерско уметничко деловање, а обухватају библиотеку, аматерско позориште, аматерске музичке и плесне групе и разне секције: представе, предавања и друге догађаје који се тамо одржавају, и с временом су чврсто установљени као средиште живота и слободног времена разних друштвених група и категорија Бугара. $\mathrm{VHECKO}^{4}$ је 2017. прогласио читалиште као „практично искуство у очувању виталности нематеријалног

2 Видети file:///C:/Users/user/Downloads/Pecob_Volume_Keliyan.pdf

3 Наведени подаци и закључци засновани су на резултатима добијеним из студије у оквиру пројекта „Локални фестивали: начин на који се локалне заједнице боре против криза”, под покровитељством Националног фонда за науку при Министарству просвете и науке (КП-06-Х45/5 од 30. 11. 2020).

${ }^{4}$ УНЕСКО Регистар добрих пракси заштите, који је успостављен 2009. године, сакупља важна искуства у заштити наслеђа и примере о томе како се заједнице широм света суочавају и успешно решавају изазове у преношењу свог наслеђа. Овај Регистар представља скуп најбољих пракси и сазнања који се могу прилагодити другим околностима за будуће нараштаје. 
културног наслеђа" (Culture statistics 2019 edition, 2019, str. 29). Према закону који регулише његове активности, читалиште је традиционално самоуправно бугарско културно и образовно удружење у насељима, које такође обавља државне културне и образовне задатке. Сви појединци могу да учествују у активностима читалишта, без обзира на године старости и пол, политичке и верске ставове и етнички идентитет. Овај културни центар заједнице је непрофитно правно лице, односно невладина организација (НВО).

На дан 31. децембра 2017. у Бугарској је деловало 3.321 читалиште, од којих 663 у градовима, а 2.658 у селима (National Statistical Institute ${ }^{5}$ ). Њихове активности се проширују и постају све разноврсније; данас, поред традиционалних аматерских позоришних, плесних и певачких ансамбала, као и група које се баве уметношћу, ови центри у последњих 30 година такође организују веома популарне течајеве страних језика и информатике, модерне спортске активности и релаксацију, разне видове друштвених контаката итд.

Године 2017. читалишта су организовала укупно 21.267 свечаности поводом значајних датума, 7.130 расправа о књигама, 24.334 прославе и фестивала и 3.762 скупова. Представљена је 1.001 музејска збирка, приказано 4.245 филмова и видео -емисија, те организовано још 1.253 културне активности. Отприлике половина читалишта у Бугарској $(48,7 \%)$ корисницима обезбеђује рачунаре са интернетом; готово сва читалишта $(91,7 \%)$ имају оперативну библиотеку, док више од три четвртине њих (76,6\%) има биоскопску/позоришну дворану (National Statistical Institute ${ }^{6}$ ).

Читалишта су центри аматерског уметничког деловања како у градовима, тако и у селима; то су институције које организују и промовишу културу. Године 2017. је у њима деловало укупно 4.607 музичких и певачких група и ансамбала, од којих 1.629 у градовима, а 2.978 у селима. Најбројније међу њима биле су групе за изворно народно певање - 2.778, у које је било укључено 30.816 људи. Још 56.640 људи учествовало је у чак 3.178 уметничких плесних група, а најпопуларнији су фолклорни ансамбли има их 2.386 и у њима игра 44.593 аматера.

Године 2017. је у овим културним центрима основано 3.077 клубова и кружока, од којих 1.327 у градским подручјима, а 1.750 у сеоским подручјима, а у њима је узело учешћа укупно 39.375 људи - 20.142 у граду, а 19.233 на селу. Ови аматерски уметнички клубови су током 2017. извели укупно 13.985 представа, међу којима предњаче позоришне представе, а после њих следи 2.197 изложби из области примењених уметности и 1.696 изложби слика (National Statistical Institute ${ }^{7}$ ).

У многим градићима, као и у сеоским подручјима, читалишта су једине културне институције; без њихових активности људи који живе у тим деловима земље били би лишени сваке могућности да присуствују културним догађајима, односно да учествују у њима. Није случајно што су ови центри познати као народна читалишта - „народни центри заједнице”.

${ }^{5}$ https://www.nsi.bg/en/content/4537/community-clubs, приступљено 30. децембра 2020. године

${ }^{6}$ https://www.nsi.bg/en/content/4543/amateur-artistic-creativity-community-cultural-centres, приступљено 30. децембра 2020. године.

${ }^{7}$ https://www.nsi.bg/en/content/4543/amateur-artistic-creativity-community-cultural-centres, accessed on December $30^{\text {th }} 2020$. 
Бугарска је чланица ЕУ већ 13 година, па се стање и развој нашег друштва пореди са осталим државама чланицама Уније према низу показатеља. Који су трендови у обрасцима доколице у нашој земљи у поређењу са онима у ЕУ? Које су сличности и разлике између нас и у којој су мери активности у слободно време у нашој земљи сличне онима (или различите од оних) у развијеним европским друштвима? Информације добијене од Статистичког уреда Европске уније, познатог као Eurostat, од Националног завода за статистику Бугарске, као и од Европске анкете о квалитету живота (EQLS) итд., представљају добар основ за проучавање доколице у Бугарској, као и за њено поређење са доколицом у осталим чланицама ЕУ.

Према подацима Eurostat-a, учесталост контаката Бугара са рођацима, пријатељима и суседима у слободно време током 2015. била је слична просеку у ЕУ, иако ми нисмо међу земљама са највећим релативним уделима сличне врсте комуникације. Бугарска је била на 13. месту, при чему је 23,8\% испитаница и 22,8\% испитаника изјавило да се друже са рођацима, пријатељима и суседима неколико пута месечно. Просек у ЕУ износио је 23,5\% за жене и 22,5\% за мушкарце (The lives of women and men in Europe, 2018 $)$.

Према показатељима који узимају у обзир учешће у броју активности у слободно време, Бугарска је на претпоследњем месту међу чланицама ЕУ, а после ње следи Румунија. Ове активности обухватају одређену врсту спорта, одлазак у биоскоп и на представе, посећивање културних места и одлазак на спортске догађаје. Релативни удео Бугара који су се током 2014. бавили спортом је релативно мали: свега 15,3\% мушкараца и 5,3\% жена у нашој земљи провело је 150 минута или више недељно бавећи се спортом или физичком активношћу ван посла. У ЕУ, релативни удео мушкараца који се баве физичком активношћу у слободно време износи $37,5 \%$, а жена 26,2\%. Подаци показују да је готово два и по пута мање мушкараца у Бугарској одабрало спорт као активност у слободно време током 2014. у односу на просек у ЕУ, док се спортским активностима бавило готово пет пута мање жена у односу на преостале чланице Уније. Један од разлога за недовољно бављење спортом међу Бугарима јесте лоша, незадовољавајућа или недоступна материјална основа (због низа разлога - финансијских, инфраструктурних и осталих), где људи могу да се баве спортом само у своје слободно време. Бугарска је имала најнижи степен задовољства спортским објектима у главном граду током 2014, при чему је Софија на последњем месту од свих престоница ЕУ: једва нешто више од трећине становника Софије (38\%) сматрало је да су спортски објекти у њиховом граду „довољно добри”.

Године 2015, отприлике 63,7 \% одраслих становника ЕУ (од 16 година и старијих) изјавило је да су одлазили у биоскоп, на представе (позоришне, концерте, организоване културне догађаје под ведрим небом итд.) или посетили неку културну установу (музеј, историјски споменик, уметничку галерију или археолошко налазиште) током претходних 12 месеци. Један од најнижих нивоа учешћа забележен је у Бугарској - 28,6\%. Код становника сеоских подручја наше земље овај удео био је најнижи у Европи, испод 10\% (Cultural statistics 2019 edition, 2019, str. 125, str. 139).

${ }^{8}$ https://www.nsi.bg/women_and_men_in_Europe_2018/bloc-3b.html?lang=bg, accessed on December $30^{\text {th }} 2020$. 
Удео одраслих становника ЕУ (од 16 година и старијих) који су изјавили да су се у 2015. бавили бар једном уметничком активношћу (током 12 месеци пре анкете) чинио је нешто више од једне трећине (35,2 \%), док је у Бугарској овај удео био око $17 \%$, односно двоструко мањи од просека у ЕУ. Приближно 83\% Бугара није се бавило никаквом културном активношћу током исте године (Ibid, str. 143).

Подаци о одласку у биоскоп до три пута током последњих 12 месеци показују да је просек у ЕУ био 28,6\% за жене и 27,4\% за мушкарце; свега 12,6\% жена (или 2,3 пута мање од просека у ЕУ) и 13,6\% мушкараца (два пута мање од просека у ЕУ) у нашој земљи изјавило је да су одлазили у биоскоп. Важно је напоменути да је $20 \%$ испитаника у Бугарској означило „недостатак заинтересованости” као главни разлог за неодлажење у биоскоп, док је мање од петине испитаника (18\%) указало на финансијске разлоге као главни мотив за неодлажење у биоскоп.

Тренд примећен као показатељ „одласка у биоскоп” исти је као у случају „одласка на представе уживо”: просечан релативни удео у ЕУ био је 30,3\% за жене и 27,7\% за мушкарце. Удео Бугарки које су одлазиле на представе био је 14\% (2,2 пута мање од просека у ЕУ) а Бугара - 11,3\% (односно два пута мање од просека у ЕУ). Главни разлог за неучествовање у овој врсти културне активности био је „недостатак заинтересованости”, забележен код 23\%, а „финансије” код $18 \%$ испитаника у Бугарској.

У чланицама ЕУ, просечан релативни удео за жене које су посетиле културне установе износио је 28\%, а 27,3\% за мушкарце. У Бугарској је овај проценат жена био два и по пута нижи од просека у ЕУ, а код мушкараца је био чак три пута нижи од европског просека. Главни разлог за неучествовање у овој врсти културне активности био је „недостатак заинтересованости”, забележен код 28\%, а „финансије” код $17 \%$ испитаника у Бугарској.

Омиљена активност Бугара у слободно време је читање књига. Године 2016, релативни удео жена које су прочитале најмање једну књигу током последњих 12 месеци износио је $61,2 \%$, а мушкараца - 45,1\%. Као што се може видети из наведених података, жене активније читају од мушкараца, са разликом од 16\% између два пола. У Бугарској новине чита 48,5\% мушкараца и 42,7\% жена свакога дана или готово свакога дана, при чему је разлика између полова нешто испод 6\% (The lives of women and men in Europe, $2018^{9}$ ).

У Бугарској је 2018. забележен најнижи релативни удео домаћинстава са приступом интернету од свих чланица ЕУ- $72 \%$ у односу на просек од $89 \%$ за овај показатељ у ЕУ исте године (Culture statistics 2019 edition, 2019, str. 153-154). Упркос најнижој раширености интернета у односу на европске земље, били смо међу оним чланицама ЕУ које активно користе мрежу. Године 2017. је просечан релативни удео за мушкарце и жене у ЕУ (старости од 16 до 74 године) који су користили интернет током последња три месеца пре анкете износио 63\% за мушкарце и $67 \%$ за жене. У Бугарској је овај удео био $82 \%$ за жене и 76\% за мушкарце - што је $15 \%$ више за жене и $13 \%$ више за мушкарце у поређењу са просеком у ЕУ. Према наведеном показатељу, Бугарска је била на четвртом месту, после Малте, Мађарске и Белгије.

\footnotetext{
${ }^{9}$ https://www.nsi.bg/women_and_men_in_Europe_2018/bloc-3b.html?lang=bg, accessed on December $30^{\text {th }} 2020$.
} 
Интернет и могућности које он нуди се Бугарској користе углавном у слободно време, а не, као што је то био случај у већини чланица ЕУ, у пословне сврхе. На пример, према показатељу „употреба интернета у тражењу посла и пријављивање за посао”, просечне вредности релативног удела жена и мушкараца у државама чланицама био је петина за сваку групу, док су ове вредности у Бугарској износиле половину просека у Унији, односно 11\% за жене и $10 \%$ за мушкарце, при чему смо били на претпоследњем месту, пре Чешке Републике. Интернет је за слање и добијање мејлова у просеку користило 87\% мушкараца и $86 \%$ жена у ЕУ, док Бугари нису били међу најактивнијим корисницима мреже у том погледу: интернет је у Бугарској за ову сврху користило 71\% жена и 70\% мушкараца.

Релативни удео Бугара који читају вести на интернету био је сличан просеку у чланицама ЕУ; проценат жена у ЕУ које читају вести на интернету у просеку је износио 70\%, у односу на проценат Бугарки од 74\%; релативан удео мушкараца у ЕУ који читају вести на интернету био је $75 \%$, а у Бугарској - 74\%. Године 2018. готово половина Бугара (47\%) је на интернету гледала телевизијски или видео програм и слушала музику; петина испитаника из наше земље је играла игрице или их преузимала са интернета. Поређења ради, просечан број људи у ЕУ који су гледали телевизијски или видео програм на интернету у истом периоду износио је мање од три четвртине (72\%), више од половине људи у ЕУ (56\%) је слушало музику на интернету, а трећина њих је играла или преузимала игрице са интернета (Culture statistics 2019 edition, 2019, str. 160, str. 155).

Удео људи у ЕУ који су куповали робу и услуге на интернету износио је 69\%, а удео оних који су куповали карте за разне догађаје износио је $27 \%$ током 2018. године. Удео корисника интернета који су куповали књиге, часописе и новине онлајн био је $22 \%$, а удео оних који су куповали филмове и музику онлајн био је $17 \%$. Насупрот томе, мање од 10\% корисника интернета у Бугарској је куповало филмове или музику онлајн - $1 \%$, књиге, часописе и новине - $2 \%$, а карте за културне догађаје - $5 \%$. Мање од трећине Бугара куповало је било коју врсту робе на интернету (Ibid, str. 168-170).

Учешће Бугара у добровољним активностима у њихово слободно време било је крајње непопуларно, што говори о ниском нивоу грађанске ангажованости у земљи. Удео одраслих становника који су учествовали у добровољним активностима у Бугарској је 2015. био мањи од 10\% (Living conditions in Europe, 2018, str. 119).

Постоје значајне структурне разлике у буџетским расходима домаћинстава у ЕУ и у Бугарској: просечни расходи за културу у домаћинствима у ЕУ су 2018. године износили 3\% од њихових укупних расхода, док су расходи бугарских домаћинстава за културу износили 1,6\% њихових укупних расхода. Док је $42 \%$ свих расхода бугарских домаћинстава за културу чинило плаћање телевизијских и радио рачуна, закупа опреме и помоћних уређаја за ове услуге, просечан релативни удео расхода за исте артикле је у ЕУ био двоструко нижи - 20\% (Ibid, str. 183).

Подела послова у породици и укљученост у активности одржавања домаћинства, као што су чишћење, кување, набавка намирница, одржавање куће, брига о члановима домаћинства итд., имали су пресудан утицај на могућности коришћења слободног времена за жене и мушкарце. Релативни удео жена у чланицама ЕУ које су на дневном плану биле посвећене кувању и одржавању куће је 2016. износио 79\%, док је удео мушкараца у истим активностима износио $34 \%$. Готово три четвртине (73\%) 
Бугарки било је укључено у разне активности у домену кућних послова, односно тај број био је за 6\% нижи од просека у ЕУ. Међутим, удео Бугара који су се бавили истим кућним пословима износио је 13\%, или 2,6 пута мање у поређењу са мушкарцима у Европи. Према показатељу „пријављена је највећа разлика између учешћа мушкараца и жена у кућним пословима”, Бугарска се нашла на трећем месту, после Грчке и Италије. Бугарски мушкарци, заједно са мушкарцима у Хрватској, најмање су учествовали у активностима одржавања домаћинства у поређењу са мушкарцима у осталим чланицама ЕУ; наиме, у кување и одржавање куће било је укључено $13 \%$ Бугара и $12 \%$ Хрвата (The lives жена and men in Europe, $2018^{10}$ ).

Године 2019, људи у ЕУ су радили у просеку 37,1 сати недељно на свом главном послу. Запослени у Бугарској су 2019. имали најдужу просечну радну седмицу од свих чланица ЕУ - радили су 40,4 сати недељно (The European Union Labour Force Survey ${ }^{11}$ ).

Према подацима Eurostat-a за 2019. годину, 9\% испитаника у Бугарској одговорило је да увек осећају временски притисак док раде; њих $31 \%$ је често под притиском, $51 \%$ - понекад, а 9\% - никада ${ }^{12}$. Можемо донети закључак да су Бугари радили у окружењу у којем влада временски притисак.

Такође смо имали и највећи проблем да постигнемо равнотежу између посла, породице и друштвених контаката. Бугарски испитаници навели су највећи степен потешкоћа у проналажењу времена и енергије за обављање кућних и породичних задатака и у довољној усредсређености на посао. Када је реч о подели према половима, жене у Бугарској су доживеле више проблема повезаних са равнотежом између посла и приватног живота. Оне су такође доживеле и брже погоршање ове равнотеже у односу на мушкарце. На пример, 70\% жена је 2016. пријавило да су „превише уморне од посла да би обављале неке кућне послове које треба да обаве” најмање неколико пута месечно, у поређењу са 68\% мушкараца (European Quality of Life Survey 2016: Quality of life, quality of public services, and quality of society, 2017, str. 41-42).

Ниски приходи негативно утичу на активности у слободно време, ограничавајући их захтевом за задовољавањем основних потреба домаћинстава. Већ годинама, од тренутка када је постала чланица ЕУ, Бугарска је све време на последњем месту када је реч о приходима. Према подацима Eurostat-a, док је просечна цена рада по сату у ЕУ 2019. за мушкарце износила 16,64 евра, а за жене - 13,72 евра, у Бугарској је била 2,52 евра за мушкарце и 2,16 евра за жене. Ниски приходи такође одређују квалитет живота у бугарском друштву ${ }^{13}$

Стварна индивидуална потрошња (AIC) је мера материјалног благостања домаћинстава. Према подацима Eurostat-a за 2019, стварна индивидуална потрошња по глави становника изражена у стандардима куповне моћи (PPS) у Бугарској

10 https://www.nsi.bg/women_and_men_in_Europe_2018/bloc-3b.html?lang=bg, accessed on December $30^{\text {th }} 2020$.

${ }^{11}$ https://ec.europa.eu/eurostat/databrowser/view/lfsa_ewhuis/default/table?lang=en, приступљено 30. децембра 2020. године

12 https://ec.europa.eu/eurostat, приступљено 30. децембра 2020. године

13 https://ec.europa.eu/eurostat/documents/portlet_file_entry/2995521/2-15122020-BP-EN.pdf/ cd3fcb0f-faee-d0ce-0916-9be3ac231210, accessed on December 30 ${ }^{\text {th }}, 2020$. 
износила је 58\% просечног нивоа у ЕУ. Године 2019, БДП по глави становника изражен у поменутим стандардима у Бугарској износио је 53\% просека у ЕУ (Ibid).

Осећање задовољства измерено у Бугарској 2016. износило је 6,4, испод просека у ЕУ од 7,4. Ова појава може се објаснити економским тешкоћама и беди у којима живи знатан део бугарског становништва. Један број испитаника пријавио је тешкоће у састављању краја с крајем - 2016. је тај број био 63\%, и даље већи од просека у ЕУ од 39\% (European Quality of Life Survey 2016: Quality of life, quality of public services, and quality of society, 2017, str. 14-16).

Криза COVID-19 изазвала је далекосежне промене током веома кратког временског периода. Електронска анкета коју је 2020. спровела Европска фондација за побољшање животних и радних услова (Eurofound) под називом „Живот, рад и COVID-19” даје увид у утицај пандемије на живот људи у чланицама ЕУ. Ова електронска анкета у којој су подаци прикупљени путем интернета спроведена је у априлу 2020, на почетку пандемије COVID-19, и поново три месеца касније, у јулу 2020. године.

Јавне здравствене мере предвићене за спречавање ширења вируса COVID-19 обухватиле су активно подстицање рада од куће за оне који су у могућности да то ураде. На много радних места у периоду закључавања почев од пролећа 2020, рад на даљину постао је уобичајен начин рада за велики број запослених који су имали ограничено или никакво претходно искуство са оваквим радом. Испитаници који су радили од куће чешће пријављују да раде и у слободно време, нарочито у домаћинствима са децом. Рад на даљину показао се као напоран за многе запослене мајке које морају да раде и да се баве онлајн наставом и воде рачуна о деци, и то све у истом временском периоду. Рад на даљину највероватније ће постати много распрострањенији после кризе на основу генерално позитивне реакције запослених и послодаваца на искуство са оваквим начином рада током пандемије COVID-19. Међутим, обимнији рад на даљину подразумева све веће губљење границе између посла и приватног живота, излажући на тај начин велики број запослених ризику од физичког и емоционалног исцрпљивања.

Електронска анкета из априла 2020. открила је да се испитаници - нарочито жене са децом млађом од 12 година - боре како би успоставили равнотежу између посла и личног живота. Наиме, иако је рад на даљину био кључни фактор у обезбеђивању континуитета пословања, он је довео и до повећаног броја људи који раде од куће, што је произвело потешкоће у управљању сукобима између посла и личног живота и повећање прековременог рада. Релативни удео запослених лица у Бугарској која раде од куће као проценат укупног броја запослених био је веома низак 2019 - свега 0,6\%, само са Румунијом иза Бугарске. Када је реч о овом показатељу, просечан удео чланица ЕУ у истом периоду био је 10,8\%. Пандемија COVID-19 променила је обрасце запослења у Европи, са релативним уделом рада на даљину који се знатно повећао 2020: просек у ЕУ био је 34\%, односно нешто више од трећине запослених, док је у Бугарској тај проценат износио $22 \%$, односно између петине и четвртине запослених Бугара (Eurofound, 2020) ${ }^{14}$.

${ }^{14}$ http://eurofound.link/covid19data, accessed on December $30^{\text {th }} 2020$. 
Од свих чланица ЕУ, највећи број анкетираних Бугара пријавио је погоршање финансијске ситуације у јулу 2020. у поређењу са априлом: њих $49 \%$ је навело овакав одговор у јулу, у поређењу са 39\% у априлу, при чему је просек у ЕУ 34\% у јулу и $30 \%$ у априлу. Ово несумњиво утиче на животно задовољство међу Бугарима ${ }^{15}$. У свих 27 држава чланица ЕУ, средња вредност животног задовољства је у априлу износила 5,5 , а у јулу 5,2: то значи да је ова вредност у Бугарској износила 6,7 у априлу и 6,3 у јулу, што указује на нижи ниво животног задовољства у поређењу са осталим земљама (Ibid).

C једне стране, због закључавања, повећава се слободно време. Ипак, с друге стране, због затварања центара за доколицу, концертних дворана, обустављања позоришних и оперских представа, итд., могућности за коришћење слободног времена знатно су смањене. Међутим, у исто време се јављају друге могућности - за онлајн активности, комуникацију, концерте, чак и одређене врсте спорта (на пример, онлајн часови јоге итд.), односно за активности код куће. Као резултат пандемије, слободно време се повећава појединим друштвеним групама, док се другима знатно смањује - на пример, родитељима деце која слушају наставу онлајн, онима који раде од куће, наставницима и осталима.

Закључак који можемо да донесемо јесте да је пандемија променила, па чак и у извесној мери избрисала границе између радног и слободног времена.

\section{REFERENCES / ЛИTEPATУPA:}

Cultural statistics: 2019 edition (2019). Luxemburg: Publication Office of the EUhttps:// ec.europa.eu/eurostat/documents/3217494/10177894/KS-01-19-712-EN-N pdf/915f828b-daae-1cca-ba54-a87e90d6b68b?t=1571393532000doi:10.2785/824495

Eurofound: Living, working and COVID-19, COVID-19 series.(2020). Luxemburg: Publication Office of the EU.https://www.eurofound.europa.eu/sites/default/files/ef_pub-

lication/field_ef_document/ef20059en.pdf.doi: 10.2806/467608.

European Quality of Life Survey 2016: Quality of life, quality of public services, and quality of society. (2017). Luxemburg: Publication Office of the EU https://www.eurofound. europa.eu/sites/default/files/ef_publication/field_ef_document/ef1733en.pdf.doi: 10.2806/964014

Eurostat website. https://ec.europa.eu/eurostat

Kelly, J. R. (1972). Work and Leisure: A Simplified Paradigm. Journal of Leisure Research, 4 (1), 50-62.

Keliyan, M. (2012). Consumption Patterns and Middle Strata: Bulgaria and Japan. PECOB, University of Bologna. Available at file://C:/Users/user/Downloads/Pecob_Volume_ Keliyan.pdf

Living conditions in Europe: 2018 edition. (2018). Luxemburg: Publication Office of the EU. https:/ec.europa.eu/eurostat/documents/3217494/9079352/KS-DZ-18-001-EN-N. pdf/884f6fec-2450-430a-b68d-f12c3012f4d0?t=1532352347000. doi: 10.2785/39876

15 Животно задовољство мери се на скали од 1 до 10, где 1 означава крајње незадовољсство, а 10 крајње задовољство. 
National Statistical Institute. https://www.nsi.bg/en

Schor, J. (1992). The Overworked American: The Unexpected Decline of Leisure. New York: Basic Books.

The European Union Labour Force Survey. https://ec.europa.eu/eurostat/databrowser/ view/lfsa_ewhuis/default/table?lang=en

The lives of women and men in Europe: Statistical portrait. (2018). Sofia: Eurostat and National Statistical Institute publ.https://www.nsi.bg/women_and_men_in_ Europe_2018/index.html?lang=bg 